オブジクト指向言語を用いた多体柔軟構造物の運動方程式導出システム*1

\title{
Formulation System of Equations of Motion for Multibody Flexible Structures by Using Object-Oriented Language
}

\author{
藤 井 裕 矩*2 武 田 重 之*2 \\ Hironori FUJII and Shigeyuki TAKEDA
}

Key Words : Large Space Structures, Structural Analysis, Object-Oriented Analysis

\begin{abstract}
Equations of motion for such multibody flexible structures as space structures containing a large number of degree of freedom is formulated by using a system written in a Object-Oriented language $\mathrm{C}++$. This paper aims to achieve the following two accomplishment: The first is a general formulation of the equations of motion for multibody flexible structures applying the extended Hamilton's principle; The second is the development of the system for the formulation and the multibody structures are analyzed by utilizing the approach of Object-Oriented analysis. The developed system constitutes a mathematical simulation program for dynamical system and is formatted in $\mathrm{C} / \mathrm{C}++$ or Mathematica or Matlab.
\end{abstract}

\section{1.はじめに}

近年のコンピュータの発達に伴って，連続系の離散 化手法や数值計算法が数多く考案され，柔軟構造物の 振動解析などの大規模な数值計算も，比較的容易に行 うことができるようになった。しかし，人間のコンピ ユータに対する要求は留まるところがなく，より大規 模な計算をさせようとしたり，より簡易な操作で直観 的な出力を求めたり，と限りなくコンピュータを利用 しようとする傾向がある。このようにコンピュータ は，研究・開発において必然的なものとなってきてい る.

オブジェクト指向という言葉が現れて約 20 年にな るがリ，計算機の発達に伴い，近年ようやくコンピュ ータにそのコンセプトを導入できるようになった。オ フジェクト指向の根本の思想は, 問題領域の自然なモ デル化であって，これは人間の直観的な発想と直接に 結び付き，問題解決にあたって非常に有効となる手法 の一つである:パーソナルコンピュータの世界では，

\footnotetext{
${ }^{* 1}$ 平成 6 年 3 月 29 日原稿受理

*2 東京都立科学技術大学
}

アップルコンピュータ社の製品であるマッキントッシ ユがオブジェクト指向を取り入れた直視覚的なコンピ ュータ環境を提供し，オブジェクト指向概念の先駆者 となった．また最近では，マイクロソフト社の MSWindows の爆発的な普及により，ほとんどすべての コンピュータに対して, 直視覚的な環境が実現され, 多くのューザーにオブジェクト指向の概念を浸透させ るのに貢献した．これらの実例は, 繁雑なコンピュー タ操作をオブジェクト指向的な環境を用いることで, 容易なものとしている。

一方で、コンピュータプログラミングの世界でもオ ブジェクト指向を取り入れた開発環境は発達した。こ れは表面の操作環境だけでなく，開発環境からオブジ ェクト指向を取り入れることで, プログラムの開発効 率, 再利用性などを高める働きを持つようになった。 現存する開発言語には C++ ${ }^{1)}$. Smalltalk ${ }^{2)}$ などの オブジェクト指向言語が有名で, ワークステーション はもちろん，PC上でのアプリケーション開発も十分 可能となってきている.

このようにオブジェクト指向応用の分野は,コンピ ュータの領域には留まらず, 工学, 医学, 生物学, 経 営学, 管理工学など、末だに応用範囲は拡がり続け。 実例報告は絶えない。

本研究では，比較的解析が複雑な多体柔軟構造物の 動的解析を対象に，その運動方程式導出にあたって， オブジェクト指向言語を用いたシステム開発を試みた ので報告する。

多体柔軟構造物は, 一般に自由度が多く大規模な運 動方程式を必要とする。通常，静的な解析において は，市販されている有限要素法を利用した解析プログ ラムが多く用いられている。一方で，三末辛はトラス 構造物の静的解析問題を対象に, 見事にオブジェクト 指向を取り入れたシミュレータの開発に成功してい る.しかし，動的解析になると振動解析を除いて，汎 
用プログラムがほとんど存在せず，各自が運動方程式 を導出して，数值シミュレーションを行う以外にな い Murotsu 他) が実施したようなロボットアーム の解析などは，特に柔軟な腕を持つ場合，繁雑な運動 方程式の導出が前提となり，解析以外に時間が多く費 やされる.

また，一度汎用の計算プログラムを開発したとして も，オブジェクト指向言語を用いないシステムである と開発効率，計算機資源の再利用性もほとんど期待て きず，将来の拡張も望むことはできないであろう.

本論文では，第一に，複数の部材によって構成され る大型宇宙構造物のような多体柔軟構造物の運動方程 式導出過程の定式化を拡張八ミルトン原理を用いて行 い，部材が構造物に㹡張される過程において，いかに して運動方程式が構成されるのかを調查した．第二 に，多体柔軟構造物をオブジェクト指向言語を用いて 運動方程式導出システムに実装した。ここでは，多体 構造物の部材の種類や接合方法の観点から，自然で人 間に直観的なモテル化を検討した。第三に，運動方程 式導出システム開発にあたって適用した，多体構造物 を濯識するアルゴリスムについて検討した。システム の自動化により，ユーザーの負担を軽減することを目 的に，多体構造物の入力やシミュレータに利用される 出力がより直観的なものであることに努めた。そして 最後に、本システムによって得られる運動方程式の適 用例を挙げ，その有用性を証明した。

\section{2. 運動方程式章出の定式化}

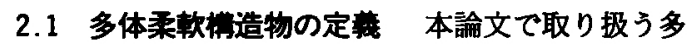
体柔軟構造物のモテルを一例として第 1 図に示す。本 論文では，暫定的な運動方程式導出システムの開発に あたり，導出されたモデルがシミンレータ実装に適当 であり，かつ取り扱いが比較的容易であることが望ま しいため, 取り报う多体柔軟構造物モテルについて, 次に挙げる 3 つの仮定を設けた。

1） 2 次元空間モデルであること. 3 次元モデルへの 対応は今後の検討課題とする.

2) 剛体および柔軟体の 2 種類の部材により棈成さ れること. 部材はそれそれが慣性空間での座標パラメ 一夕を有し，2 次元空間では水平位置座標 $(:=x)^{* 3}$, 垂直位置座標 $(:=y)$ 坫上び姿勢角 $(:=\theta)$ の $3 つ$ のパラメータがそれに該当する．剛体は，部材重量 $(:=m)$ 扔よび部材慣性モーメント $\left(:=I_{\mathrm{a}}\right)$ を物理 特性パラメータとして持ち，任意形状かつ，部材上任 意の位置で他部材と接合出来るものとする．柔軟体

\footnotetext{
*8ここて，(：=x)は，例えば， $x$ で水平位置を表現すること を示す
}

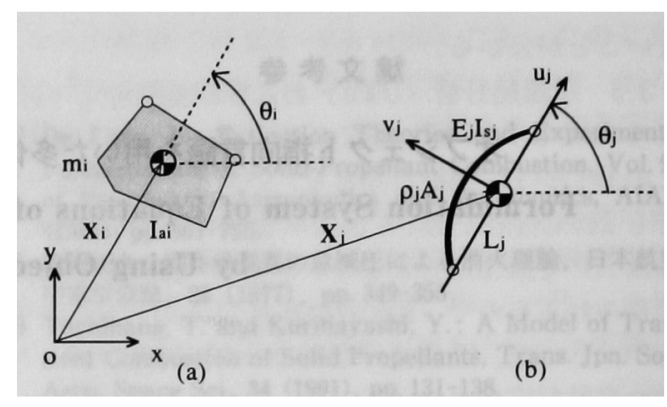

第 1 図多体柔軟棈造物を構成する闰体(a)お゙よび柔軟体 (b)

は，オイラー・ベルヌーイ梁を仮定し, 材料密度 (： $=\rho)$, 梁断面積 $(:=A)$, 梁ヤング率 $(:=E)$, 梁断 面二次モーメント $\left(:=I_{\mathrm{s}}\right)$ および梁長さ $(:=L)$ を 物理特性パラメータとして持ち，梁の両端のみで他部 材と接合可能とする.

3）接合方法はピン接合および固定接合の 2 種類に よること.また 1 筒所の接合部ては, 任意数の部材が これら2つの接合方法を任意の組み合わせで実現する ことができるものとする.

2.2 拡張ハミルトン原理") の適用 運動方程式の 導出には，物体のもつ作用積分の変分を用いて極值問 題を設定し，運動方程式を導出する抬張ハミルトン原 理を適用した．拡張ハミルトン原理から得られるラグ ランジュ方程式を用いた導出方法は，他の論文にも多

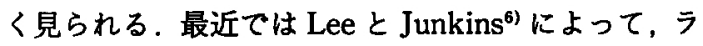
グランジュ方程式を使った，本体固定柔軟アームの運 動方程式の一般的な定式化についての報告がある. 特 に柔軟体の扱いが重要であって，Fujii 他 ${ }^{7) や J u n-~}$ kins 他") が扱っているスルーマヌーバーモテルでは， 偏钽分方程式で表される運動方程式を導出しており， これは，柔軟体を最も厳密に定式化できるためであ る.これらの理由で, 拡張ハミルトン原理の適用は, ユーザーが運動方程式を利用する場合に要求される， 運動方程式の厳密性を備えた最適の導出方法であると 考えられる。

ここで, 多体柔軟構造物の運動方程式拿出知識の基 本となる，単部材の運動方程式を学出した場合, 剛体

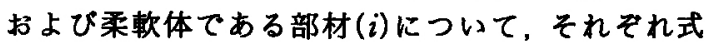
(1)および式 (2)を得る.

$$
\begin{aligned}
& \int_{0}^{t}\left\{m_{i} \delta X_{i}^{\mathrm{T}} \dot{X}_{i}+I_{\mathrm{a} i} \delta \theta_{i} \ddot{\theta}_{i}\right\} d t=0 \\
& \int_{0}^{t}\left\{\int _ { L _ { j } } \left[E_{j} I_{\mathrm{s} j} \delta V_{j}^{\mathrm{T}} V_{j}^{\prime \prime \prime \prime}+\rho_{j} A_{j}\left(\delta X_{j}^{\mathrm{T}} \ddot{Z}_{j}\right.\right.\right. \\
& \left.\left.\left.\quad+\delta \theta_{j} V_{j}^{\mathrm{T}} \frac{\partial C_{j}^{\mathrm{T}}}{\partial \theta_{j}} \ddot{Z}_{j}+\delta V_{j}^{\mathrm{T}} C_{j}^{\mathrm{T}} \ddot{Z}_{j}\right)\right] d u_{j}\right\} d t=0
\end{aligned}
$$


ただし， $i=1, \cdots, N$.

ここで， $m_{i}, I_{\mathrm{a} i}, \rho_{i}, A_{i}, E_{i}, I_{s i}$ および $L_{i}$ はそれぞれ， 部材重量, 慣性モーメント、部材密度, 梁断面積, 梁 ヤング率, 梁断面二次モーメントおよび梁長さを表 し，また， $\boldsymbol{Z}_{i}, \boldsymbol{X}_{i}, \boldsymbol{C}_{\boldsymbol{i}}$ および $\boldsymbol{V}_{\boldsymbol{i}}$ はそれぞれ慣性空間 座標ベクトル，並進座標ベクトル，姿勢角行列および 部材上局所座標べクトルを表し,さらに $\boldsymbol{Z}_{i}=\boldsymbol{X}_{i}$ $+C_{i} V_{i}$ の関係を満たしている。 また，(”) は時間微 分，( )'は空間微分を表わす。ここでは，簡単化の ため, 制御入力については省略する。

2.3 棈造物の運動方程式 (1) 2 つ以上の部材が 接合して構造物を構成する場合，それぞれの接合部の 慣性座標が等しいという関係から，拘束式が生じる. つまり一方の座標変数により他方の座標が表現できる ことから，構造物全体の自由度が滅少する。ここで は，本論文て取り扱う 2 種類の接合方法のそれぞれに 対して㭘証する.

最も簡単な構造物として, 柔軟部材 $(i)$ の右端杖よ び柔軟部材 $(i+1)$ の左端が接合して構成された構造物 の場合，接合による拘束式として次式を得る。

$$
\left.\boldsymbol{Z}_{i+1}\right|_{\mathrm{L}}=\left.\boldsymbol{Z}_{\boldsymbol{i}}\right|_{\mathrm{R}}
$$

ここで, $\left.\boldsymbol{Z}_{i+1}\right|_{\mathrm{L}}$ および $\left.\boldsymbol{Z}_{\boldsymbol{i}}\right|_{\mathrm{R}}$ はそれぞれ，柔軟部材 $(i)$ 右端の慣性座標招よび柔軟部材 $(i+1)$ 左端の慣性座標 を表す。このときの拘束式として，ピン接合および固 定接合の場合についてそれぞれ次のように，式(4)お よび式( 5 )を得る。

$$
\begin{aligned}
& X_{i+1}=X_{i}+\left.C_{i} V_{i}\right|_{\mathrm{L}}-\left.C_{i+1} V_{i+1}\right|_{\mathrm{R}} \\
& X_{i+1}=X_{i}+C_{i}\left(\left.V_{i}\right|_{\mathrm{L}}-\left.C_{i, i+1} V_{i+1}\right|_{\mathrm{R}}\right)
\end{aligned}
$$

ここで，定数である $\left.V_{i}\right|_{\mathrm{L}}$ およ゙ $\left.\boldsymbol{V}_{\boldsymbol{i}+\mathrm{1}}\right|_{\mathrm{R}}$ はそれぞれ部 材 $(i)$ の左端局所座標および部材 $(i+1)$ の右端局所座 標を表し，同じく定数である $C_{i, i+1}$ は部材 $(i)$ に対す る部材 $(i+1)$ の相対姿勢角行列て, $C_{i+1}=C_{i} \boldsymbol{C}_{i, i+1}$ の 関係を満たす。両式共に, 部材 $(i+1)$ の並進座標 $\boldsymbol{X}_{i+1}$ をその他の座標パラメータで表すことで, 2 次元 慣性空間では自由度が 2 個減少することが分かる。 た式 ( 5 )の固定接合の場合の拘束式では，部材 $(i+1)$ の慣性空間姿勢角行列 $\boldsymbol{C}_{i+1}$ を部材 (i)の慣性空間姿勢 角項 $C_{i}$ で表すことで,さらに自由度が 1 個隇少す る。

2.4 標造物の運動方程式 (2） 構造物を構成する 部材が 3 つ以上である場合, 部材がループを構成する 場合が考えられる．ここでは部材として部材 (1)，部 材 (2)，部材 (3)を構成要素とした第 2 図のような例 を取り上げる．この場合， 2.3 節の手順で 3 つの拘束 式が得られる。ささらにそれら 3 つの式を組み合わせる と，次式のような拘束式を得る.

$$
C_{1}\left(\left.V_{1}\right|_{L}-\left.V_{1}\right|_{R}\right)+C_{2}\left(\left.V_{2}\right|_{L}-\left.V_{2}\right|_{R}\right)+C_{3}\left(\left.V_{3}\right|_{L}-\left.V_{3}\right|_{R}\right)
$$

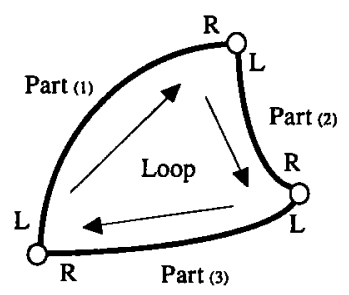

第 2 図 ループを構成する部材

$=0$

つまり，それぞれの姿勢角行列が互いに拘束し合い， ループを構成する部材の 1 つの姿勢角行列（例えば $\left.C_{1}\right)$ をその他のループ構成部材の姿勢角行列 $\left(C_{2}, C_{3}\right)$ によって表すことができる.この性質は 3 部材ループ の場合に限らず, 任意数で構成されるループでも同様 で, 通常 1 ループにつき 1 自由度減少することが、式 （6）から容易に推測できる.

また 2 つのループが隣接している場合，それぞれの 拘束式が得られる。乙して連立方程式を解くことによ って，2つの姿勢角行列を他の部材によって表すこと が出来,これより 2 自由度が減少する。

ここで注意することは，圥長な拘束式を得た場合に は, 必要十分な式を選択しなくてはならないこの選 択についての判断に関して, 今後実装を検討する必要 がある.

\section{3. オブジェクト指向言語 $\mathrm{C}++$ の適用}

3.1 オブジェクト指向言語の特徵 近年オブジェ クト指向を用いた研究が多くの研究者によってなさ れ，その有用性が示されてきた，最近では三木 り，トラス構造物をオブジェクト指向言語でモデル化 し，静的特性を解析するシミュレータの開発に成功し ている.

オブジェクト指向を用いた解析法は, 問題を細分化 して，その小問題を互いに有機的に結び付けながらそ れぞれの問題解決の役割を明確にする．同様な性質を 持つものは小問題グループにまとめ, 幾つかの小問題 の組み合わせにより解が得られる問題はそれら小問題 の上位問題として配置するなど, 各問題の適切な位置 付けがオブジェクト指向解析を有効にする鍵となる. 三末 ${ }^{3)}$ の研究では大きな問題を 1 つのトラス構造物の 静的挙動解析に設定し, 小問題をトラス構造物を構成 する部材や接合点など, それぞれの静的特性問題とす ることで問題解決に成功している，また，機械部品の 組み立てを問題の対象にしたChen 他") のモデル化 も，各々の部品に関する知識を有機的に，また階層的 に表現して,オブジェクト指向を応用したものであ 
る.

オブジェクト指向の考え万には，開発効率，保守 性，拡張性などが優れているという利点があり，多く はコンピュータプログラム上でその実力を発揮する． これらの利点は，1）カプセル化，2）継承，3）多態 性といった，オブジェクト指向の 3 大特徴 ${ }^{10)}$ により もたらされるものである.カプセル化とは，クラス (C++でのオブジェクトの呼称) で所持しているデー タをクラス単位で管理し、データに対するクラス外部 からのアクセス制限を行うものである。この機能によ り。内部のデータは保護され，不当な外部からのアク セスは受け付けない，また，既存のクラスに対してよ り特殊なテータ型や手続きを持つクラスを定義する場 合，継承の機能を利用する．開発者は，既存クラスの 機能に対して, 追加や変更をするデータおよび手続き を，継承先クラスの定義で追加記述するだけで新しい クラスとして利用できる．多態性とは同じ手続き名で あっても作用させるクラスによってそれぞれが固有の 動作を定義できることである。つまり．手続き名の同 一化により．さまさまなクラスに対する操作を統一的 に行うことができる。

一般に知られているオブジェクト指向言語には， Smalltalk, C++, Modula-2 といったものがある. Smalltalk の歴史は長く，その開発環境はほほ完成さ れており、今でも多くのユーザーの支持を得ている. 三末光の研究で開発されたシミニレータを記述してい るのも Smalltalkである。一方, 従来のC言語に才 ブジクト指向機能を追加した C+十は, 未だ改版中 であるにもかかわらず，機能的には Smalltalk と 同等もしくはそれ以上の性能を有する. 現在ではオフ ジェクト指向言語といえぱ, Smalltalkもしくは C+十が挙げられ，より柔軟な $\mathrm{C}+$ +の需要が高まり つつある.

本研究でのオブジェクト指向言語の適用には, 運動 方程式の学出に目的を絞ったシステムの開発に際し て、次のような理由によりオブシェクト指向言語 C十+を採用した。

1）大学研究機関ては，多くの研究者が数值計算プ ログラムをCで記述している．Cのューザーが C+十に移行するのは自然な流れであり，近い将来 C+十のユーザー人口が増えることが予測される．

2) コンパイラ言語であるため, システムの実行速 度が比較的速い。

3）ほとんどすべてのコンピュータに安価な $\mathrm{C}++$ コンパイラが存在する．つまり，ほとんどすへての環 境で本システムが利用できることになる。

こうした理由から，オブジェクト指向言語 C+十を
選択したわけだが，多機能で高速な $\mathrm{C}++$ 性能を最 大限に引き出すのはあくまでも開発者の能力にかかっ ている. 本システムの開発にあたっては，十分なシス テム設計と，随時再利用性のチェックや可読性向上の 工夫を行うことで，最良のコードを記述するように努 めた。

3.2 多体柔軟棰造物への適用多体柔軟構造物 (:=Structure；以下クラス名を表す) に対してクラ スを設計する場合, 多体柔軟構造物モデルの第 3 図 (a)のようなイメージから，オブジェクトは第 3 図 (b)のような構成要素で構成されていると考えられ る.ここでは, 1 つの多体柔軟構造物は, 複数の部材 $(:=$ Part $)$ が接合点 $(:=$ Joint $)$ によって接合して, 形成したものと考えられる.このように部材や接合点 を有機的につなげる事で, 直観的に各クラスを把㩧て き, システム開発のプログラム設計面て大いに役に立 つ.この構造物の表現は、三木 ${ }^{3)} や\left(\mathrm{Chen}^{9)}\right.$ のモテル 化に類似する。

さらに構成要素を検証すると，第 3 図(a)のように 部材同士の接合はそれそれの部材上の接点 $(:=$ Contact Point）を接合点が接合しているものと認識でき 了.

また，第 4 図(a)のように，各部材クラスはそれぞ

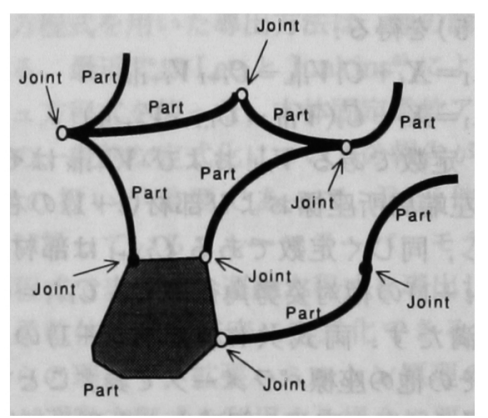

(a) 現実世界のモデ

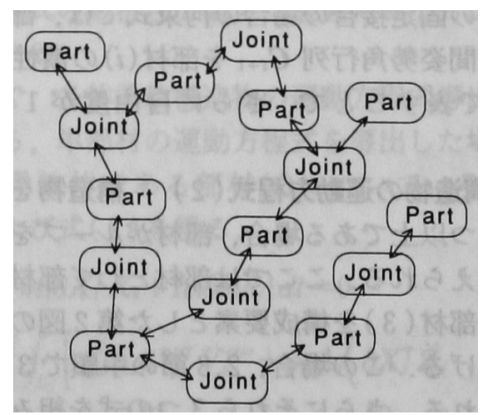

(b) オプシェクトモア゙ル

第 3 図多体柔軟满造物モデル 


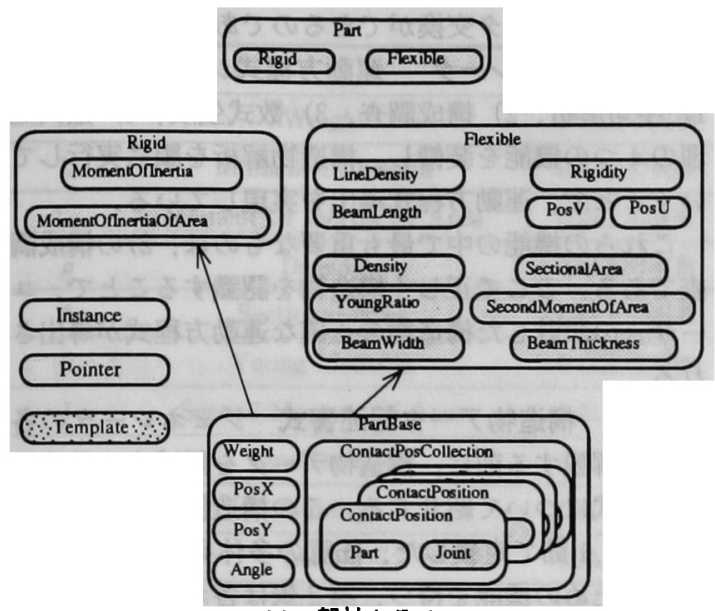

(a) 部材クラス

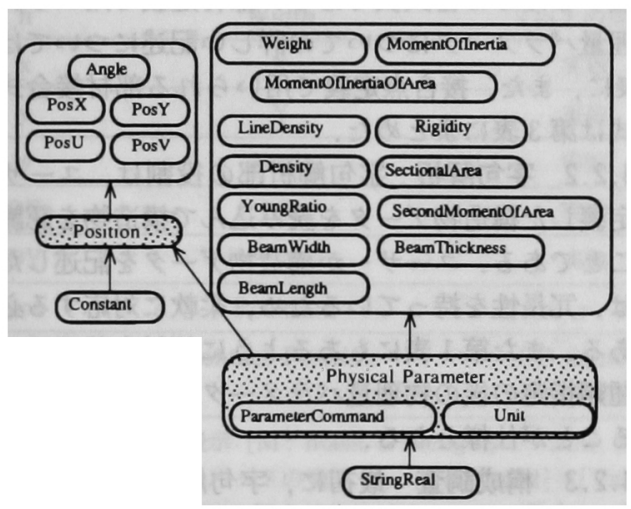

(b) 物理量クラス

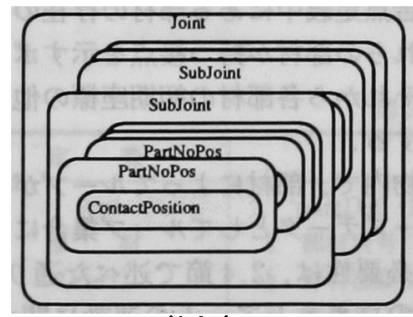

(c) 接合点クラス

第 4 図 多体柔軟楼造物の棈成要素

れが物理特性パラメータおよび座標パラメータを所持 している。この図は, 用体 (:=Rigid) および柔軟体 (:=Flexible) のそれぞれのクラス構成図も示してい る.ここで共通パラメー夕は, 共通部材クラス（：= Part Base）にまとめた．この設定により．刪体クラ スおよび柔軟体クラスは，それそれが共通部材クラス からデータと手続きを継承し，固有のパラメータを追 加郡述することで実現した。また部材は一度に，剛 体、柔軟体のうちどちらか一方の部材にしか成り得な

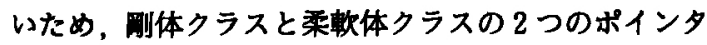

(メモリの場所を表す変数)を装備し，必要に応じてど ちらか一方を生成するように設計した。

部材の要素である物理特性パラメータ（：=Physical Parameter) 切よび座標パラメータ (: = Position) は，第 4 図(b)のようなオブジェクトモデルによって 構成される.物理特性パラメータは定数の物理量であ り、データとしてクラス名固有の名称と単位を所持し ている．この名称と単位は，ユーザーが入力する多体 柔軟構造物のデータを読み取る際に必要になる．座標 パラメータは，実数值を持つことが共通てあるため， 物理特性パラメータおよび一定属性（：=Constant） から機能を継承して，定数を変数に拡張して実現し た。

接合点は，任意数の部材が任意のピン接合および固 定接合の組み合わせで接合している点を示す。よって 接合点クラスのデー夕構造は, 第 4 図(c)のように 2 段の線形りスト構造より成り立ち，下段の固定接合て は互いに姿勢角が拘束され，上段のピン接合では互い に独立な自由度である.下段の要素である接合部材要 素クラス ( : = Part No Pos) には，接点クラスを示 すポインタをデータ要素として装備している．このポ インタは接合している部材クラスの接点の格納場所を 示しており，これをアクセスすることで，接合してい る部材情報を得ることができる．

ここで, 第 3 図で構造物の接合イメージを示した が, 実際には部材わよび接合点クラスの管理を統一的 にするため，構造物クラスには，部材集合クラス，接 合点集合クラス,ループ構造集合クラス ( : = Loop Collection) およびベース部材クラス ( : = Base Part) をデータとして装備した，一方で, 部材クラスと接合 点クラスは，既に接点クラスによって有機的な結合が なされており，さらにリストで部材および接合点クラ スを管理することは，冗長であるかのように思われ る.しかし，部材集合を統括的に扱う場合には，線形 リスト棈造であるほうが効率的であると考えられるた め，両方法を採用した。

構造物の要素であるループ構造集合クラスは、構造 物内の部材によるループ構造クラス（：=Loop）の集 合である. 本システムは，2.4 節に示したようなルー プ検索を構造物に対して施し，運動方程式基出のため の情報としてループ構造集合クラスに貯える。

またペース部材クラスは，棈造物のベース部材の部 材番号を保持したクラスである。

\section{4. システム權成}

4.1 全システム样成 運動方程式望出システムの 全体構成を第 5 図に示す. 全システムは，多体柔軟構 


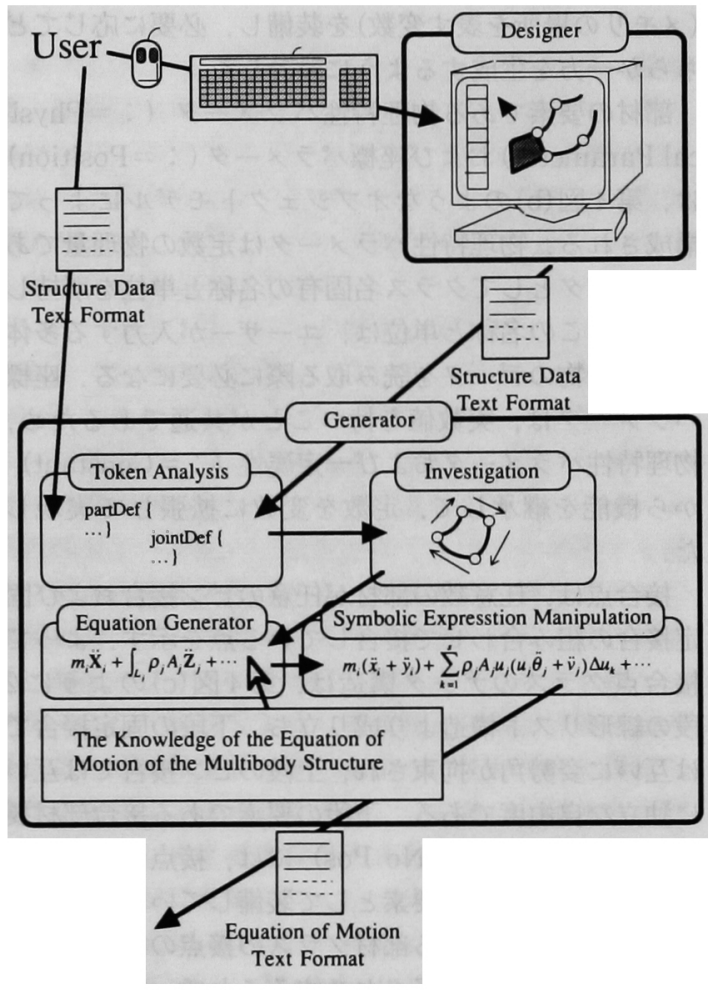

第 5 図運動方程式尊出システム

造物を設計するためのデザイナー，および実際に多体 柔軟構造物データを解析して，運動方程式を出力する

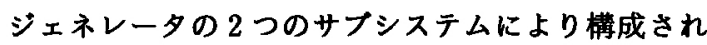
る.ここで，デザイナーは，オブシェクト指向システ ム構想の一㻴として加えたものであり，運動方程式導 出には必須ではなく，ユーザーは，構造物データを直 接ジェレータに与えることで運動方程式を得ること がてきる。よって，本システムの運動方程式尊出方法 には，デザイナーを使用する場合と直接ジェネレータ を使用する場合の 2 通りがあり，本論文では，既に実 用段陼にある後者の方法のみを紹介する.

運動方程式尊出の手順は，次の通りである．1）工 一ザーは、ワードプロセッサを用いて，多体柔軟構造 物のデータを作成する．2）ジェネレータを起動して 構造物データを与える．3）ジェネレータは構造物の 解析を行い, 出力として多体柔軟構造物の運動方程式 を提供する。標準の出力形式は， C 言語で記述された シミュレータへの実装を想定した.

ここで重要なことは，ジェネレータの入出力データ は，テキスト形式であることである。つまり，データ 形式はハードウェアに依存しないため，この運動方程 式学出システムが導入されているコンピュータ間で
は，容易にデータ交換ができるのである．

4.2 ジネレータ 運動方程式ジェネレータは， 1）字句解析，2）構成調查，3）数式生成，4）数式処 理の 4 つの機能を装備し，構造物解析を順に実行して いくことで，運動方程式導出を実現している．

これらの機能の中て最も重要なものは，2）の構成調 查である.ここで正しく構造物を認識することて，ュ ーザーの設計した構造物の正確な運動方程式が導出さ れる。

4.2.1 模造物データ記述書式 ジェネレータの各 機能を解説する前に，構造物テータを記述するための 記述書式について紹介する．この構造物デー夕記述書 式は，2.1節で定義した，任意の多体柔軟構造物を表 現するための機能を持つ. 第 2 表は各オブジェクトを 定義するための書式表である. 部材定義で用いられる 物理量パラメータについての詳しい記述については第 1 表に，また，接合点定義で用いられる部材接合式の 書式は第 3 表にまとめた.

4.2.2 字句解析 字句解析部の役割は、ユーザー が定義した構造物データを読み込んで構造物を認識す ることである.ユーザーが構造物データを記述した場 合は，て長性を持っているため，柔軟に対応する必要 がある。また第 1 表にもあるように部材定義ては，部 材種類指定の後の物理量パラメータの指定は任意順て あることが仕様となる。

4.2.3 棈成調查 最初に，字句解析部て認識した 部材定義と接合点定義の整合性を調へ，さらに構造物 テータの接合点定義中にある部材の存在の有無を調へ る. 次にそれらの部材が持つ接点を示すポインタをセ ットする.それから各部材の初期座標の他部材との整 合性を検査する．

次に構造物内で，部材によってルーブが構成されて いれば、ループデーとしてループ集合に貯える.ル ープ検出の必要性は，2.4 節で述へた通りであるが, Wang 他 ${ }^{11}$ のロボットアームの運動に関する研究て も、複雑に連なったアームのループ構造を検出し，運 動方程式の拘束条件として取り入れている. 本論文て は、ループ検出アルゴリスムを無向グラフ閉路探索問 題として捉らえ，本システム用に独自に考案した。

ループ検索には，再㷌という手法を用いている。再 㷌とは，ある関数が自分自身を呼び出してプログラム を実行するという技法である．ここでは，部材から部 材へと移動を重ね、ループとなる部材の集合を検索し ている.同じ部材を検索しないためには何手目の移動 でその部材に到達したかを記憶させ，以前より手数が 少ない場合や検索を済ませてない場合に限り，他の部 材への移動を許可する．移動先の部材がない場合は， 
第1表 物 理 量

\begin{tabular}{|c|c|c|c|c|c|c|}
\hline 記号 & 命 & 值 & 単位*1) & タイプ*2) & 部材 & 依存性 \\
\hline $\mathrm{m}$ & Weight- & 0 以上の実数 & M1 & 定数 & 剛体 & 必須 \\
\hline$I_{a}$ & Moment Of Inertia & 0 以上の実数 & M1L4 & 定数 & 剛体 & 必須 \\
\hline$I_{\text {BS }}$ & Moment Of Inertia Of Area & 0 以上の実数 & L4 & 定数 & 剛体 & $-->I_{B}$ \\
\hline$\rho$ & Density & 0 以上の実数 & M1L-3 & 定数 & 柔軟体 & $--\rho \mathrm{A}$ \\
\hline A & Sectional Area & 0 以上の実数 & L2 & 定数 & 柔軟体 & $--\rho \mathrm{A}$ \\
\hline $\mathrm{E}$ & Young Modulus & 0 以上の実数 & M1L-2 & 定数 & 柔軟体 & $-->\mathrm{EI}$ \\
\hline I & Second Moment Of Area & 0 以上の実数 & L4 & 定数 & 柔軟体 & $-->\mathrm{EI}$ \\
\hline$\rho \mathrm{A}$ & Line Density & 0 以上の実数 & M1L-1 & 定数 & 柔軟体 & 必須 \\
\hline EI & Rigidity & 0 以上の実数 & M1L2 & 定数 & 柔軟体 & 必須 \\
\hline $\mathrm{L}$ & Length & 0 以上の実数 & $\mathrm{L} 1$ & 定数 & 柔軟体 & 必須 \\
\hline$t$ & Thickness & 0 以上の実数 & Ll & 定数 & 柔軟体 & $->t^{*} h=A$ \\
\hline $\mathrm{h}$ & Width & 0 以上の実数 & L1 & 定数 & 柔軟体 & $-->t^{*} h=A$ \\
\hline $\mathbf{x}$ & $\mathrm{X}$ & 実数 & L1 & 変数 & 共通 & $-->$ pos \\
\hline $\mathrm{y}$ & $\mathrm{Y}$ & 実数 & $\mathrm{Ll}$ & 変数 & 共通 & $-\rightarrow>$ pos \\
\hline$\theta$ & Angle & 実数 & (R1) & 変数 & 共通 & $-->$ pos \\
\hline $\mathrm{DX}$ & DX & 実数 & $\mathrm{L} 1$ & 定数 & 剛体 & $-->\mathrm{cp}$ \\
\hline DY & DY & 実数 & L1 & 定数 & 剛体 & $-->c p$ \\
\hline pos & Position & $(x, y, \theta)$ & 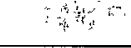 & 複合 & 共通 & 必須 \\
\hline $\mathrm{cp}$ & Contact Position & $\begin{array}{c}\text { ((ID number, } \\
\text { DX, DY)..) }\end{array}$ & 3 & 複合 & 剛体 & 必須 \\
\hline
\end{tabular}

*1) $M L T(R)$ 次元表示 [M : mass, $\mathrm{L}$ : length, T : time, R : angle]

*2) 定数であるパラメータの書式は, '[Command]=[Value][Unit]', 変数であるパラメータの書式は, '[Command] =[Value] [Unit]〈“const”〉', 複合であるパラメータの書式は, '[Command]=[Value]'などである.

第 2 表 多体柔軟構造物データ定義書式

\begin{tabular}{|c|c|}
\hline 定 & 式 \\
\hline $\begin{array}{l}\text { 部 材 } \\
\text { (Part) }\end{array}$ & 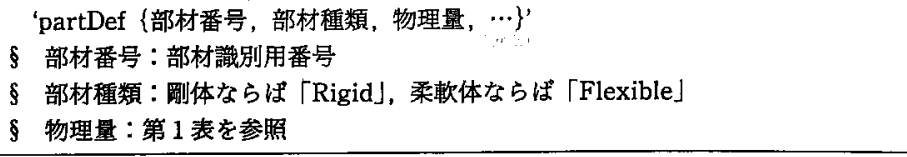 \\
\hline $\begin{array}{l}\text { 接合点 } \\
\text { (Joint) }\end{array}$ & $\begin{array}{l}\text { 'jointDef }\{\text { 接合点番号, 接合部材式 }\} \text { ' } \\
\S \text { 接合点番号：接合点識別用番号 } \\
\S \text { 接合部材式：第 } 3 \text { 表を参照 }\end{array}$ \\
\hline ベース部材 & $\begin{array}{l}\text { 'partBase }=\{\text { ベース部材番号 }\} ' \\
\text { § ベース部材番号：ベースになる部材番号，部材定義の必要有 }\end{array}$ \\
\hline $\begin{array}{l}\text { アクチュエータ } \\
\text { (Actuator) }\end{array}$ & $\begin{array}{l}\text { 'actuatorDef=\{アクチュエータ番号, } \cdots\} \text { ' } \\
\text { §アクチュエータ番号: アクチュエータ識別用番号 }\end{array}$ \\
\hline $\begin{array}{l}\text { センサー } \\
\text { (Sensor) }\end{array}$ & $\begin{array}{c}\text { 'sensorDef }=\{\text { センサー番号, } \cdots\} \text { ' } \\
\S \text { センサー番号 : センサー識別番号 }\end{array}$ \\
\hline $\begin{array}{l}\text { コメント } \\
\text { (Comment) }\end{array}$ & 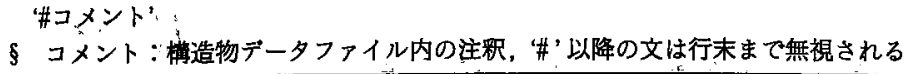 \\
\hline
\end{tabular}


第 3 表 接合点定義における部材接合式

\begin{tabular}{c|c}
\hline 部材接合式*3) & 接合方法 \\
\hline $\mathrm{A} * \mathrm{~B}$ & $\mathrm{~A}$ と B を固定結合 \\
\hline $\mathrm{A}+\mathrm{B}$ & $\mathrm{A}$ と B とピン結合 \\
\hline
\end{tabular}

*3) A と B は，部材接点または，部材接合式，部材接点の書 式は，䣓体の場合， '[部材番号]D[接点番号]'，柔軟体の場 合, '[部材番号]L'または，“[部材番号]R'.

一つ手前の部材へ後退して再びループを検索する.も しループが見つかつた場合，保存してきた検索経路を もとに，多体構造物のループ集合にループデータを加 える。

しかし，このアルゴリズムだけでは，必要十分なル ープによる拘束式を得ることはできず，圥長なループ データを検索する場合がある。これは, 数式処理の段 階で調查すべき問題であるとして，ループに関するこ こでの処理は完了する.

ついで，固定接合で，姿勢角項の自由度を共有する 部材単位にグループ分けを行い，グループ番号をそれ ぞれの部材に与えることで，部材同士の依存関係を認 識させる。

最後に, ベース部材から各部材への最短到達経路を 調查し,グループ単位で最もベースに近い部材をサブ ベースとする．この段階でベース，サブベース，その 他の部材という階層構造を作り出し，効率的な数式生 成のための準備を行う.

4.2.4 数式生成 構成調查で求めた構造物に対す る部材接合情報を元に，各部材について運動方程式を 生成する。運動方程式の生成は, 最短経路に沿って行

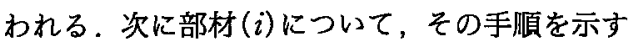

1) ペース部材の並進座標 $\boldsymbol{X}_{\mathrm{Base}}$ に関する運動方程 式を生成する.

2）ペース部材の姿勢角 $\theta_{\text {Base }}$ に関する運動方程式を 生成する。

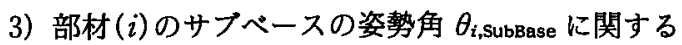
運動方程式を生成する。

4) もし柔軟体ならば，部材 $(i)$ の曲げ変位 $V_{i}$ に関 する運動方程式を生成する。

5）最短経路情報中の部材 $(k)$ が、ベース部材にな るまで, 部材 $(k)$ のサブベースの姿勢角 $\theta_{k, \text { SubBase }}$ に関 する運動方程式を生成する。

6) 終了

ここで生成される，連続系でかつ行列変数を用いた運 動方程式を中間コードと呼ぶことにして, 次の数式処 理に渡す。

4.2 .5 数式処理 この機能は実現していないが, 近い将来に到達できるであろう動作使用の概要につい
て述べる。

ここでは，各部材に分散した運動方程式をまとめ て，中間コードであった式を，数值シミュレーション 用に展開および整理する. 行列変数は, あらかじめ用 意した変換テーブルを元に各要素に展開する．また； 連続系の積分式は，ここでは柔軟体にのみに存在する 式であるので, 有限要素法を適用した一般解を準備 し，それを元に各要素に変換する，そして，同類項ご とにまとめて，数值計算でそのまま使用できるファイ ル形式に変換する. 出力ファイル形式は, C 言語関数 形式を標準とする。

\section{5. 多体柔軟宇宙棈造物モテルへの適用}

\section{1 運動方程式導出システムの適用環境 本論文} で紹介している，運動方程式導出システムの開発に は，ハードウェアとしてセイコーエプソン社の PC486 SR, OS としてセイコーエプソン社の MS-DOS ver. 5.0R el. 2 およびC++コンパイラとしてボーラ ンド社の Borland $\mathrm{C}++$ ver. 3.1 を使用した. システ ムが使用する関数は，コンパイラやハードウェアに依 存しないものを選び, 現在まだ行っていないが, UNIX上への移植も検討中である.

この節では，運動方程式導出システムの有効性を示 すために，1つの多体柔軟構造物モデルに対してシス テムを適用し，出力結果の確かさを検証した．ただ し，現段階では，4.2.5 節の数式処理部が未完成であ るため, 4.2.4 節の数式生成によって得られた中間コ ードによる結果を用いている。ここでの中間コードに よる表現は，システムの性能評価をする上で十分な出 カであると思われる。

5.2 適用例一2 リンク双腕ロボットモテルー 第 6 図に示す，2リンク双腕ロボットモデル対して， システムの適用を試みた。このロボットは，剛体を本 体とし，2本の柔軟なマニピュレータを備えて，慣性 空間内を自由に移動するものである．ただし，右腕 の，本体から見て 2 リンク目は，1リンク目に対して 直角に固定されているものとする．構造物データファ イルには第 7 図(a)を用意した。第 7 図(b)は適用後 の中間コードによる出力である.この出力結果を数式 に変換すると，式(7)〜(15)を得る。これらの式は， システムを用いないで導出した運動方程式と一致する ことは容易に確認できる。

$$
\begin{aligned}
& m_{1} \ddot{X}_{1}+\int_{L_{2}} \rho_{2} A_{2} \ddot{Z}_{2}+\int_{L_{8}} \rho_{3} A_{3} \ddot{Z}_{3}+\int_{L_{4}} \rho_{4} A_{4} \ddot{Z}_{4} \\
& \quad+\int_{L_{5}} \rho_{5} A_{5} \ddot{Z}_{5}=0 \\
& I_{\mathrm{a} 1} \ddot{\theta}_{1}+\left.\int_{L_{2}} \rho_{2} A_{2} V_{1}^{\mathrm{T}}\right|_{\mathrm{D} 1} \frac{\partial C_{1}^{\mathrm{T}}}{\partial \theta_{1}} \ddot{Z}_{2}
\end{aligned}
$$




$$
\begin{aligned}
& +\left.\int_{L_{3}} \rho_{3} A_{3} V_{1}^{\mathrm{T}}\right|_{\mathrm{D} 1} \frac{\partial C_{1}^{\mathrm{T}}}{\partial \theta_{1}} \ddot{Z}_{3} \\
& +\left.\int_{L_{4}} \rho_{4} A_{4} V_{1}^{\mathrm{T}}\right|_{\mathrm{D} 2} \frac{\partial C_{1}^{\mathrm{T}}}{\partial \theta_{1}} \ddot{Z}_{4}
\end{aligned}
$$

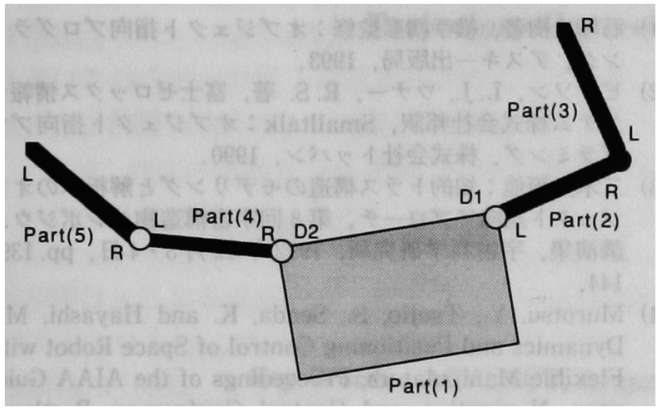

第 6 図 2リンク双腕ロボットモデル

$$
\begin{aligned}
& +\left.\int_{L_{5}} \rho_{5} A_{5} V_{1}^{\mathrm{T}}\right|_{\mathrm{D} 2} \frac{\partial C_{1}^{\mathrm{T}}}{\partial \theta_{1}} \ddot{Z}_{5}=0 \\
& \int_{L_{2}} \rho_{2} A_{2}\left(V_{2}^{\mathrm{T}}-\left.V_{2}^{\mathrm{T}}\right|_{\mathrm{L}}\right) C_{2,2}^{\mathrm{T}} \frac{\partial C_{2}^{\mathrm{T}}}{\partial \theta_{2}} \ddot{Z}_{2} \\
& +\int_{L_{3}} \rho_{3} A_{3}\left(V_{3}^{\mathrm{T}}-\left.V_{3}^{\mathrm{T}}\right|_{\mathrm{L}}\right) C_{3,2}^{\mathrm{T}} \frac{\partial C_{2}^{\mathrm{T}}}{\partial \theta_{2}} \ddot{Z}_{3} \\
& \quad+\int_{L_{3}} \rho_{3} A_{3}\left(\left.V_{2}^{\mathrm{T}}\right|_{\mathrm{R}}-\left.V_{2}^{\mathrm{T}}\right|_{\mathrm{L}}\right) C_{2,2}^{\mathrm{T}} \frac{\partial C_{2}^{\mathrm{T}}}{\partial \theta_{2}} \ddot{Z}_{3}=0 \\
& \int_{L_{2}}\left(\rho_{2} A_{2} C_{2}^{\mathrm{T}} \ddot{Z}_{2}+E_{2} I_{\mathrm{s} 2} V_{2}^{\prime \prime \prime \prime}\right)=0 \\
& \int_{L_{3}}\left(\rho_{3} A_{3} C_{3}^{\mathrm{T}} \ddot{Z}_{3}+E_{3} I_{\mathrm{s} 3} V_{3}^{\prime \prime \prime \prime}\right)=0 \\
& \int_{L_{4}} \rho_{4} A_{4}\left(V_{4}^{\mathrm{T}}-\left.V_{4}^{\mathrm{T}}\right|_{\mathrm{R}}\right) C_{4,4}^{\mathrm{T}} \frac{\partial C_{4}^{\mathrm{T}}}{\partial \theta_{4}} \ddot{Z}_{4} \\
& \quad+\int_{L_{5}} \rho_{5} A_{5}\left(\left.V_{4}^{\mathrm{T}}\right|_{\mathrm{L}}-\left.V_{4}^{\mathrm{T}}\right|_{\mathrm{R}}\right) C_{4,4}^{\mathrm{T}} \frac{\partial C_{4}^{\mathrm{T}}}{\partial \theta_{4}} \ddot{Z}_{5}=0
\end{aligned}
$$

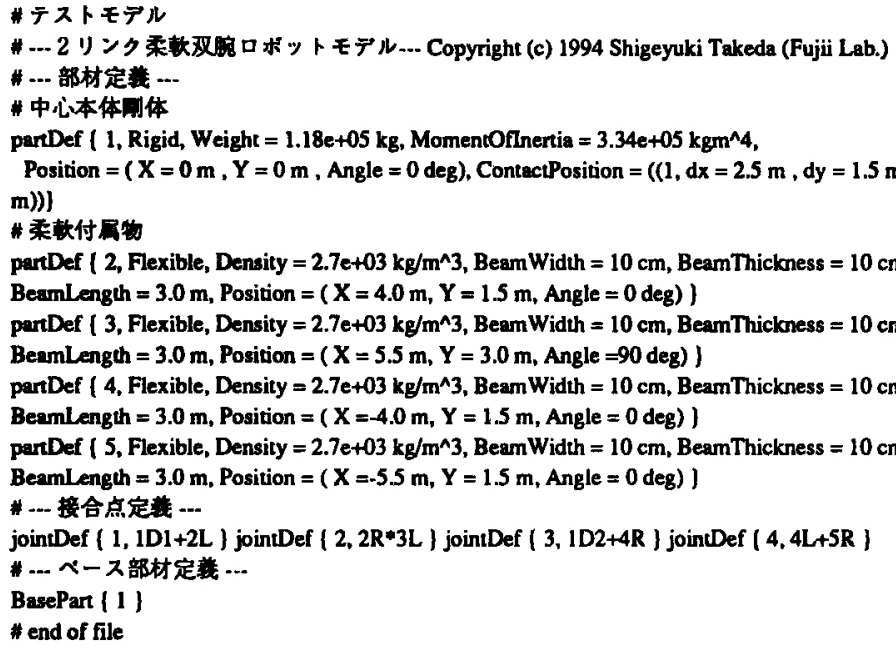

(a) 掅造物入カファイル

$\operatorname{Pan}(1)->$

$X:[+M 1 * D[X 1,(t, 2)]+I n t e g r a t e[R o u 2 * A 2 * D[Z 2,(t, 2)], L 2]+$ Integrate $[R o u 3 * A 3 * D[Z 3,\{t, 2\}], L 3]+$ Integrate $[R o u 4 * A 4 * D[Z 4$, $(1,2)]$, LA]+Iniegrate[Row5*A5*D $[Z 5,(L, 2)], L 5])$

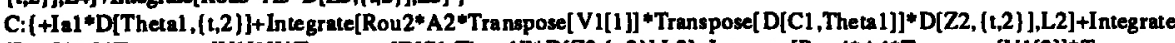
[Rou**A3*Transpose[V1[1]]*Transpose[D[C1,Thetal] $\left.{ }^{*} D[Z 3,(L, 2)], L 3\right]+$ Integrate[Rou4*A4*Transpose[V $[(2]]^{*}$ Transpose

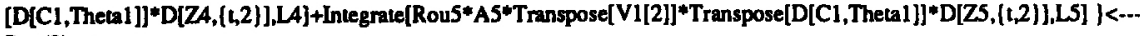

Pan(2)-->

$C:[+$ Integrate[Rou2*A2*(Transpose[V2]-Transpose[V2[1]])*Transpose $[C 2,2] * \operatorname{Transpose}[D[C 2, T h e 122]] * D[Z 2,[(, 2)], L 2]+$ Integrate[Rou 3*A3*(Transpose[V3]-Transpose[V3[1]]*Transpose[C3,2]*Transpose[D[C2,Theta2]]*D[Z3, [t,2]],L3]+ Integrate[Rou 3*A3*(Transpose[ V2[2]]-Transpose[V2[1]])*Transpose[C2,2]*Transpose[D[C2,Theta2] $\left.\left.{ }^{*} D[Z 3,\{t, 2\}], L 3\right]\right]$

V: $\{$ +Incegrate $[R o u 2 * A 2 *$ Transpose $[C 2] * D[Z 2,\{t, 2)\}+E 2 * I s 2 * D[V 2,(u 2,4\}], L 2]\}<\cdots$

Parr(3)-.->

V: $\{+$ Integrate $[R o u 3 * A 3 *$ Transpose $[C 3] * D[Z 3,(t, 2\}]+E 3 * I s 3 * D[V 3,[u 3,4]], L 3]\}<-$.

Part(4)--->

C: $\{$ +Integrate[Rou4*A4* (Transpose[V4]-Transpose[V4[2]])*Transpose[C4,4]*Transpose[D[C4,Theta4]]*D[Z4, $(t, 2)], L 4]+$ Integrate[Rou5*A5*(Transpose[V4[1]]-Transpose[V4[2]])*Transpose[C4,4]*Transpose[D[C4,Theta4]]*D[Z5, (L,2)],L5] ] $V:(+I n i e g r a t e[R o u 4 * A 4 * T r a n s p o s e[C 4] * D[Z 4,(t, 2)]+E 4 * I s 4 * D[V 4,[u 4,4]], L 4]\}<\cdots$

Parn(5)--->

C: (+Integrate[Rou5*A5*(Transpose[V5]-Transpose[V5[2]])*Transpose[C5,5]*Transpose[D[C5,Theta5]]*D[Z5, (t,2)],L5] ) V: (+Integrate[Rous*A5*Transpose $[C 5] * D[25,(t, 2)]+E 5 * I s 5 * D[V 5,(u 5,4\}], L, 5]\}<--$.

$$
\text { (b) 生成された中間コード }
$$




$$
\begin{aligned}
& \int_{L_{4}}\left(\rho_{4} A_{4} C_{4}^{\mathrm{T}} \ddot{Z}_{4}+E_{4} I_{54} V_{4}^{\prime \prime \prime \prime}\right)=0 \\
& \int_{L_{5}} \rho_{5} A_{5}\left(V_{5}^{\mathrm{T}}-\left.V_{5}^{\mathrm{T}}\right|_{R}\right) C_{5,5}^{\mathrm{T}} \frac{\partial C_{5}^{\mathrm{T}}}{\partial \theta_{5}} \ddot{Z}_{5}=0 \\
& \int_{L_{5}}\left(\rho_{5} A_{5} C_{5}^{\mathrm{T}} \ddot{Z}_{5}+E_{5} I_{\mathrm{S5}} \boldsymbol{V}_{5}^{\prime \prime \prime \prime}\right)=0
\end{aligned}
$$$$
\text { 6. ま と め }
$$

\section{6. ま と め}

複雑な多体柔軟宇宙構造物の運動方程式導出を支援 する，運動方程式導出システムの設計・開発を試みた. このとき, システム開発の効率化, 構造物の自然なモ デル化, 実用性, 将来拡張の可能性を目的に，オブジ ェクト指向言語 $\mathrm{C}++$ を適用した。

その結果, システム開発には十分に効力を発揮し， 十分に検討した基礎部分により。システム全体の構築 が進むにつれて，開発速度は上がった．また，構造物 のモデルとプログラム上で扱うオブジェクトを 1 対 1 に自然に対応させることで，構造物各部のそれぞれの 関係の把握が容易になり、コーディングをする上で常 に構造物が対象であることを見失うことはなかった。 また本来の目的である，多体柔軟構造物の方程式導出 に成功し，構造物全体の運動方程式を検証するには十 分な結果を得ることができた．

しかし末完成部分を含めて, 問題点はいくつかあ る.

1）構造物が含む, 部材ループの検索は成功したが. 必要十分な拘束条件式を得るにはどのような方 法を取ればよいか

2）数式処理に最も適した中間コードとはいかなる ものか.

3）出力する運動方程式の書式は，C言語, Mathmatica および Matlabへの対応で十分か.

今後は, これらの問題を検討しながら, システムの 未完成部分である, 運動方程式ジェネレータ内の数式 処理部の開発に努め, 数值シミュレータ実装を早期に
実現するようにシステム構築が進められていく必要が ある。

\section{参考文献}

1）石塚圭樹著，横手蜻彦監修：オブジェクト指向プログラミ ング,アスキー出版局, 1993.

2）ピンソン，L.J., ウナー，R.S. 著, 富士ぜロックス情報シ ステム株式会社邦訳, Smalltalk：オブジェクト指向プロ グラミング，怢式会社トッパン, 1990.

3）三木光籍他：知的トラス構造のモデリングと解析へのオフ シェクト指向アプローチ，第 8 回宇宙構造物シンポジウム 講演集, 宇宙科学研究所, 1992 年 12 月 $3 \cdot 4$ 日, pp. 139144 .

4) Murotsu, Y., Tsujio, S., Senda, K. and Hayashi, M.: Dynamics and Positioning Control of Space Robot with Flexible Manipulators, Proceedings of the AIAA Guidance, Navigation and Control Conference, Portland, Oregon, August 20-22, 1990, pp. 735-742.

5) Arnold, V. I., Translated by Vogtmann, K. and Weinstein, A. . Mathematical Methods of Classical Mechanics, 2nd ed., Springer-Verlag, New York, 1989, pp. 59-61.

6) Lee, S. and Junkins, J. L.: Explicit Generalization of Lagrange's Equations for Hybrid Coordinate Dynamical Systems, J. Guidance, Control, and Dynamics, 15 (1992), pp. 1443-1452.

7) Fujii, H., Ohtsuka, T. and Udou, S. : Mission Function Control for a Slew Maneuver Experiment, J. Guidance, Control, and Dynamics, 14 (1991), pp. 986-992.

8) Junkins, J. L., Rahman, Z.H. and Bang, H.: NearMinimum-Time Control of Distributed Parameter Systems: Analytical and Experimental Results, J. Guidance, Control, and Dynamics, 14 (1991), pp. 406-415.

9) Chen, C. L. and Pao, P. Y.: An Integration of Neural Network and Rule-Based Systems for Design and Planing of Mechanical Assemblies, IEEE Trans. System, Man and Cybernetics, 23 (1993), pp. 1359-1371.

10) Borland International 著, ボーランド株式会社 編訳： Turbo C++ Introduction，ホーーランド株式会社，1992， pp. 151-154.

11) Wang, L.T. and Chen, C.C.: On the Numerical Kinematic Analysis of General Parallel Robotic Manipulators, IEEE Trans. Robotics and Automation, 9 (1993), pp. 272-285. 